\title{
One way introgression of a subspecific sex chromosome marker in a hybrid zone
}

\author{
C. FERRIS ${ }^{1 *}$, J. M. RUBIO' ${ }^{1}$, L. SERRANO ${ }^{2}$, J. GOSALVEZ ${ }^{2}$ \& G. M. HEWITT ${ }^{1}$ \\ 'School of Biological Sciences, University of East Anglia, Norwich NR4 7TJ, U.K. and 'Departamento de Biologia, \\ Universidad Autonoma de Madrid, E-28049, Madrid, Spain
}

\begin{abstract}
A hybrid zone occurs along the ridge of the Pyrenees between two subspecies of the meadow grasshopper Chorthippus parallelus. C-banding reveals differences between the chromosomes of these two subspecies, especially for the $\mathrm{X}$ chromosome. One $\mathrm{C}$-band is closely associated with an active nucleolar organizing region (NOR) on the $\mathrm{X}$ chromosome of C.p. parallelus but is absent from C.p. erythropus and can be used as a marker to follow the NOR. The cline for this marker is very narrow $(1 \mathrm{~km})$ and shows remarkable non-coincidence with other clines. It is displaced to the south by $5 \mathrm{~km}$ at $\mathrm{Col}$ du Pourtalet and $15 \mathrm{~km}$ at Col de la Quillane. Recombinants between the marker and other subspecific bands occur but are infrequent. The causes and consequences of such non-coincidence of clines are discussed.
\end{abstract}

Keywords: grasshoppers, hybrid zones, insect cytogenetics, introgression, non-coincident clines, nucleolar organizing regions (NORs).

\section{Introduction}

Many species and species complexes are geographically subdivided into clearly distinct subspecies and races which form hybrid zones where they meet. Such genetic confrontations are interesting not only in their own right as frequent taxonomic divisions that may lead to speciation but also because they provide excellent opportunities to study a number of evolutionary processes in action (Barton \& Hewitt, 1985, 1989; Hewitt, 1988, 1989). A general feature of these hybrid zones is that the many characters which differ between the two hybridizing taxa change at the same place forming coincident clines. However, the width of these clines may differ - they are not concordant. The most likely explanation for these features is that the clines formed following secondary contact and hybridization of two genomes that had previously diverged in allopatry. Those characters that are equally fit in any mixture will introgress progressively producing ever wider clines whereas characters which show reduced hybrid fitness will tend to form narrow clines, in a balance between the amount of dispersal and the strength of selection. Such tension zones are determined by dispersal and selection against hybrid genomes and will come to rest and be trapped by

*Correspondence. regions of low density or dispersal (Hewitt, 1975; Barton, 1979; Barton \& Hewitt, 1985, 1989) and this will tend to hold together clines for different genes. When such tension clines overlap they will also attract each other toward greater coincidence.

Another explanation for a hybrid zone depends on environmental adaptation. If a character difference between the two hybridizing taxa provides adaptation to somewhat different environments, then the centre of its cline should rest at the point of equal fitness in the ecotone. There is no reason to expect this point to be in the same place for all characters and genes, which may respond to different environmental gradients, and these may not be coincident nor concordant (Hewitt, 1988). Furthermore, we may expect diverged genomes to possess negatively heterotic, neutral and environmentally adaptive gene differences and there are a number of hybrid zones that show evidence of all these features (Barton \& Hewitt, 1985, 1989).

Concordance amongst clines can be produced when the selection against heterozygotes is the same intensity for the genes under consideration and/or the environmental gradients to which they are adaptive are the same width. Such a result would seem to be largely a matter of chance. Concordance can also be produced by strong epistatic interactions between coevolved loci, so that selection tends to maintain the parental coadapted combinations of alleles and characters, 
giving clines of similar width. Such a case has been revealed in Bombina bombina/variegata (Szymura \& Barton, 1986).

On a broad scale we may expect these determinants to act in concert: secondary contact between two diverged and internally coadapted genes may well occur at, or come to rest at, an ecotone between environments that favour alternative types (Hewitt, 1988). On the local scale, however, the population structure will modify dispersal rates and hence the shape of the clines may be different between localities. Environmental gradients are also likely to differ among localities producing different cline widths for the same character. To understand these interactions between selection, dispersal and ecology, it would seem best to pursue detailed investigations of many facets of a hybrid zone in different locations. Such an approach has been particularly productive in organisms such as the alpine grasshopper Podisma pedestris (Barton \& Hewitt, 1981, 1989; Nichols \& Hewitt, 1986, 1988), the fire-bellied toad Bombina (Szymura \& Barton, 1986, 1991), the Australian grasshopper Caledia captiva (Shaw et al., 1985; Marchant et al., 1988), the neo-tropical butterfly Heliconius (Mallet \& Barton, 1989; Mallet et al., 1990), the house mouse Mus (Vanlerberghe et al., 1988; Moulia et al., 1992) and the meadow grasshopper Chorthippus parallelus (Butlin \& Hewitt, 1985; Hewitt, 1990).

The hybrid zone in Chorthippus parallelus occurs between the Northern European subspecies C.p. parallelus and the Spanish subspecies C.p. erythropus. It runs along the Pyrenean ridge for the most part and the subspecies meet in cols below about $2000 \mathrm{~m}$, which is the altitudinal limit for this species. The two subspecies are obviously different in a number of morphological and behavioural characters (Butlin \& Hewitt, 1985; Butlin \& Ritchie, 1991) and also show some allozyme (Butlin \& Hewitt, 1985; M. Duijm, personal communication) and chromosomal differences (Gosalvez et al., 1988). Our work to date has concentrated on the hybrid zones found in two high cols towards the western and eastern ends of the high Pyrenees: Col du Pourtalet and Col de la Quillane. These represent relatively simple secondary postglacial contacts (Hewitt, 1990) with each having its own local distribution of vegetation and grasshoppers. The clines for these various characters show a range of widths through these cols, some like pronotum ratio and echeme interval (the time between chirps in the male calling song) being very narrow and changing over about $1 \mathrm{~km}$ at Col de la Quillane. Some are intermediate and others are very wide clines, as for characters such as song syllable length and the esterase 2 allozyme locus, which are some $15-20 \mathrm{~km}$ wide. Furthermore, there are differences in cline widths between the two cols, with those at $\mathrm{Col} \mathrm{du}$ Pourtalet being generally wider than those at Col de la Quillane (Hewitt, 1990). More detailed sampling and analysis of morphological characters throughout the two cols (Butlin et al., 1991) confirmed that the clines were not concordant within each col, and differed in width between cols, but it also showed that at this finer scale they were not exactly coincident, with their centres clustered over $2-3 \mathrm{~km}$ at Col de la Quillane and spread over some $15 \mathrm{~km}$ at Col du Pourtalet. There are very few reported examples of non-coincidence (Barton \& Hewitt, 1985, 1989; Hewitt, 1985, 1989) although this may in part arise from the detail required to distinguish it from broad coincidence, as was so in $C$. parallelus. Clearly further analysis of this in the laboratory and in nature is required to provide the necessary data for resolving the possible genetic and ecological causes of this phenomenon.

Along with courtship song and number of stridulatory pegs in the male, the presence of a nucleolar organizing region (NOR) on the sex chromosome $(\mathrm{X})$ in C.p. parallelus from North of the Pyrenees (in addition to the two NORs found on the $\mathrm{L}_{2}$ and $\mathrm{L}_{3}$ chromosomes in C.p. erythropus south of the Pyrenees) is one of the most distinguishing features of the subspecies (Gosalvez et al., 1988). This XNOR is situated in or next to a distinctive C-band which can be used as a marker for the XNOR ribosomal sequences. We have carried out detailed sampling through the two cols and analysed them for the presence of this XNOR C-band. This has revealed a remarkable lack of coincidence.

\section{Materials and methods}

Collections of adult males were made in early August of 1988 and 1989 through Col du Pourtalet and Col de la Quillane in the Pyrenees (Fig. 1). The testes were fixed in 3:1 ethanol:acetic acid and stored at $4^{\circ} \mathrm{C}$. Testis follicles were squashed in a drop of 45 per cent acetic acid, the coverslips removed using liquid nitrogen and the preparations aged for 1-3 days before banding. The C-band method using Giemsa staining was carried out according to Bella et al. (1986), with slight modifications. Photographs were taken with a Zeiss III photomicroscope using Kodak plus $\mathrm{X}$ film.

The C-banding reveals a number of differences between the karyotypes of C.p. parallelus and C.p. erythropus from the Pyrenees, the most prominent of which are detailed in Table 1 and Fig. 2. These are more readily resolved in embryonic material but the presence of an XNOR C-band, the marker used in this study, is clearly distinguished in meiotic tissue. Large testis size providing many meiotic divisions and field 
Fig. 1 Frequency distribution of the parallelus type XNOR C-band through two Pyrenean cols, Col du Pourtalet (a and b), and Col de la Quillane (c). The proportion of males carrying the XNOR C-band is given by the black proportion of the pie diagrams.
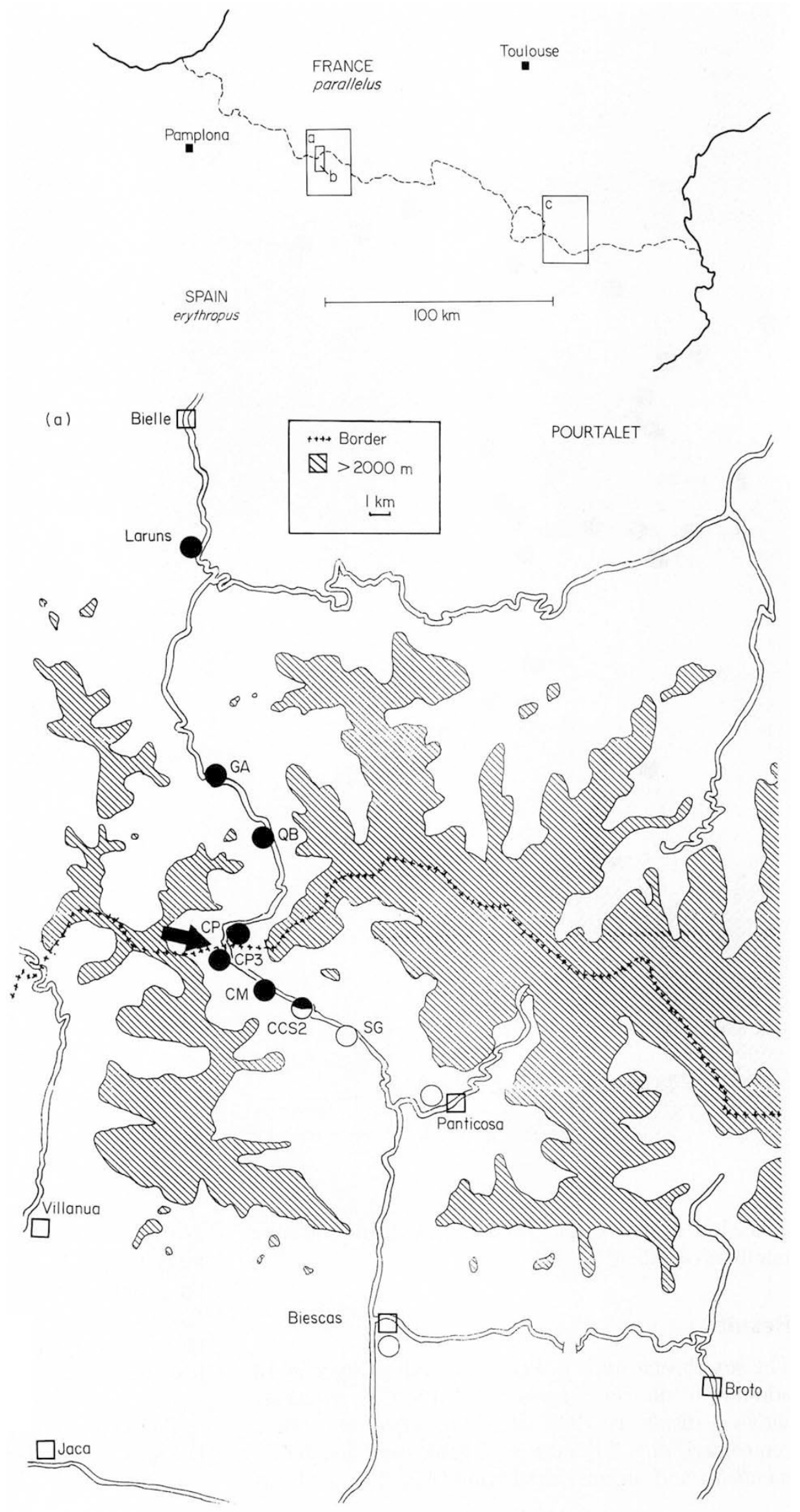


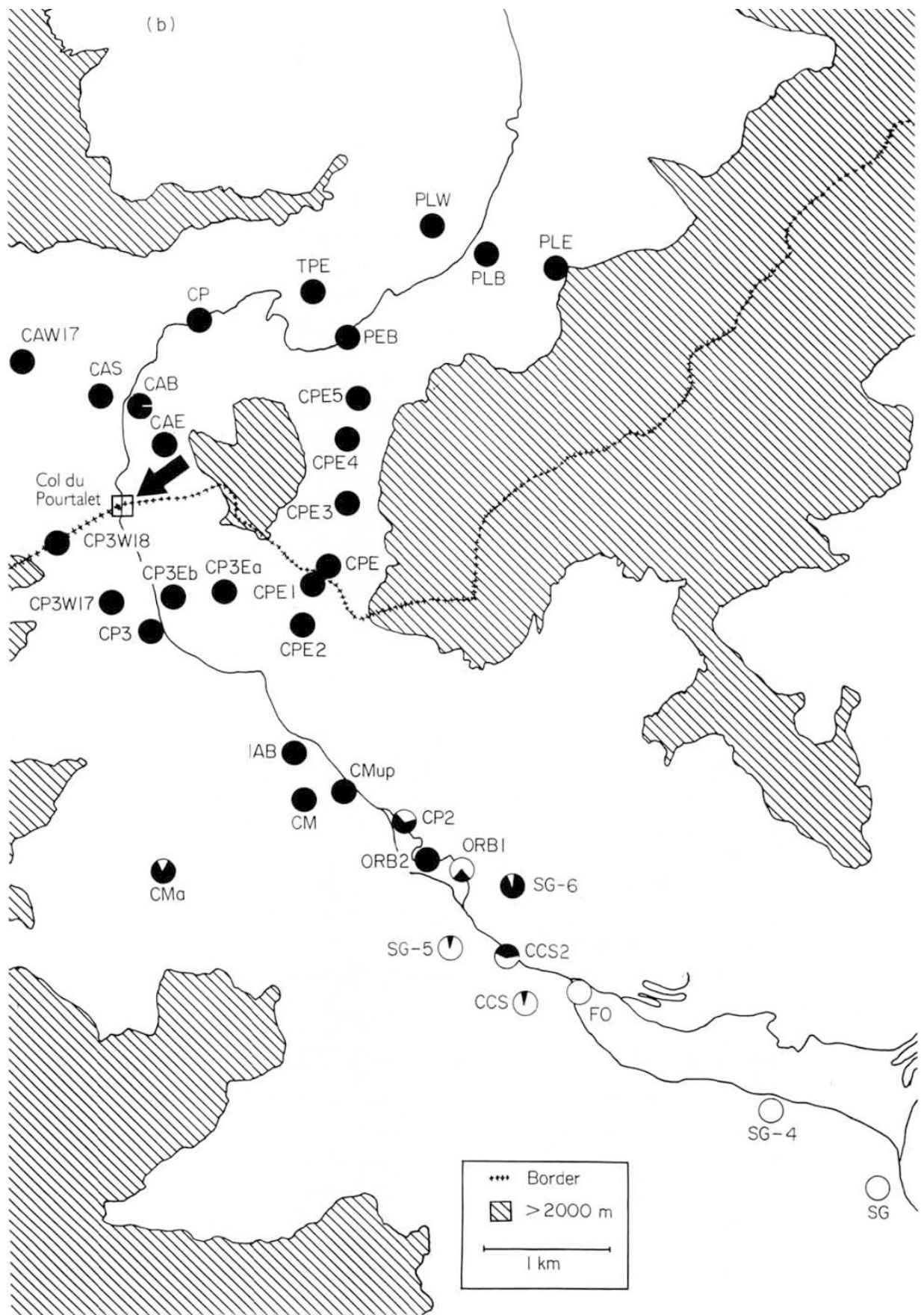

Fig. 1 Continued

collection of males, thus permits the scoring of large numbers of individuals.

\section{Results}

The sex chromosome is distinct in both subspecies. In addition to the centromeric band (P1) C.p. parallelus shows a distal one (P2); while C.p. erythropus has a centromeric one (E1) indistinguishable from that in C.p. parallelus and an interstitial band (E2) (Fig. 2). P2 is associated with active rDNA (Bella et al., 1990). These morphological types are easily distinguishable through the contact regions. We will refer to CPp X C-band and Cpe X C-band for each morphological type on the basis of these markers, although we have evidence that occasional recombinant forms do occur (see Discussion).

The locations of the populations analysed are shown in Fig. 1 and the frequency of individuals carrying the 
Fig. 1 Continued

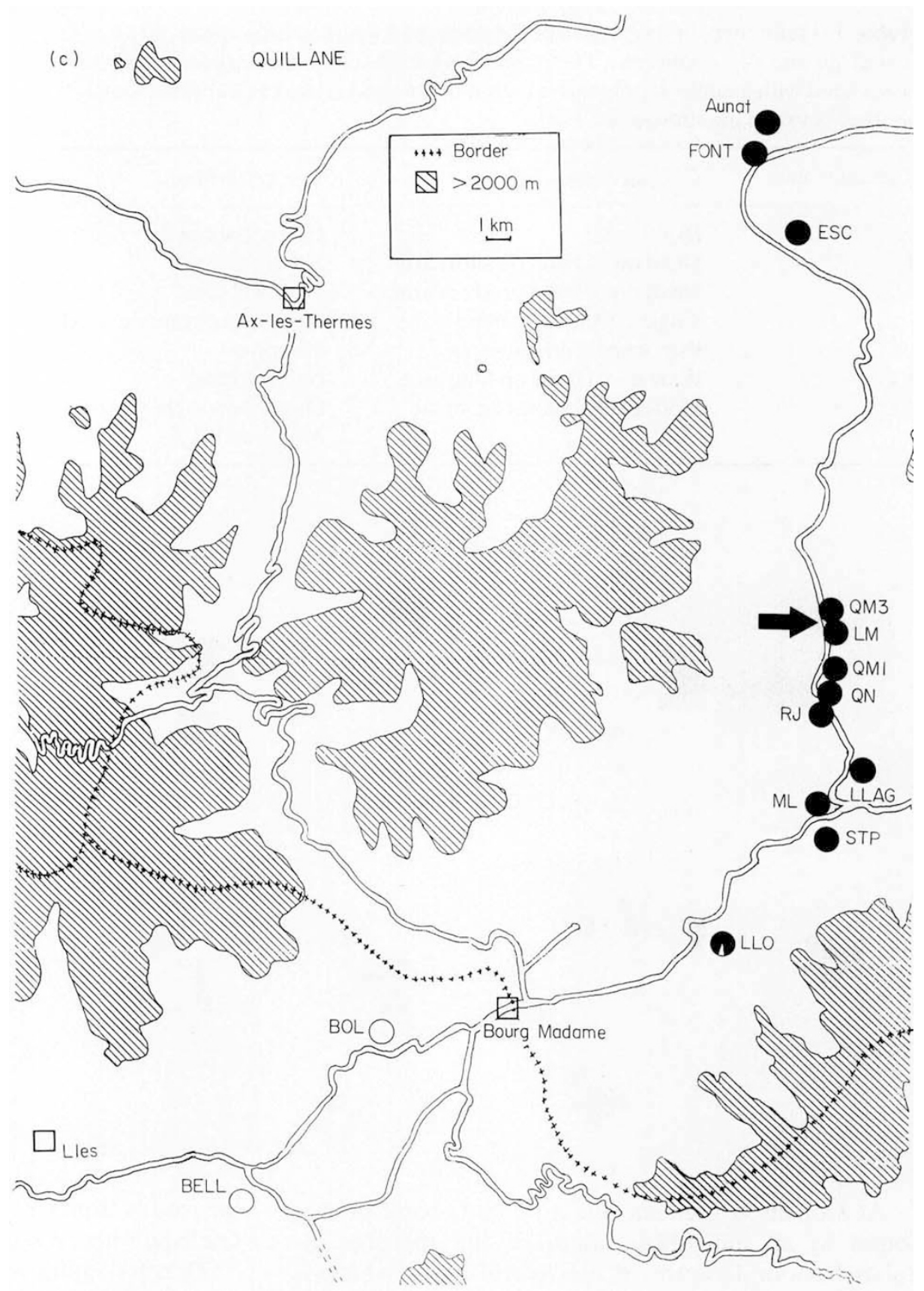

Cpp X C-band are shown as pie diagrams; the data are listed in Table 2.

The Col du Pourtalet is the overall centre for the morphological and behavioural clines comprising the hybrid zone. However, it is clear from these data that all individuals possess a Cpp $\mathrm{X} \mathrm{C}$-band on the north side of the mountain and through the col down to some $5 \mathrm{~km}$ on the south side. The change over to the Cpe $\mathrm{X}$ $\mathrm{C}$-band pattern, with an interstitial band and no XNOR C-band, occurs just south of Corral de las Mulas (CM) and all collections south of Formigal (FO) are fixed for the Cpe C-band pattern. The cline for the X C-band pattern from $C p p$ to $C p e$ is evidently very narrow being of the order of $1 \mathrm{~km}$ but the samples available do not fit a smooth cline. It is possible that there is some degree of patchiness in the distribution of chromosome types and the cline may not run perpendicular to the transect. Some samples were relatively small and further collections are necessary to define it more exactly. In the collections from this transition region we have also observed X chromosomes with an interstitial and distal C-band. We suspect these are recombinants (see Discussion). 
Table 1 Differences in the pattern of C-banding between chromosomes of C.p. parallelus and C.p. erythropus. The parallelus distal band on the $\mathrm{X}$ chromosome is associated with a nucleolar organiser region (NOR) and is used as a chromosomal marker between the subspecies

\begin{tabular}{lll}
\hline Chromosome & C.p.parallelus & C.p.erythropus \\
\hline $\mathrm{X}$ & Distal band & Interstitial band \\
$\mathrm{L}_{1}$ & Small distal band on short arm & No distal band \\
$\mathrm{L}_{2}$ & Small distal band on short arm & No distal band \\
& Single centromeric band & Double centromeric band \\
& Pair of spots on long arm & No spots \\
$\mathrm{L}_{3}$ & Wide distal band on long arm & Narrow band \\
$\mathrm{M}_{6}$ & Moderately heterochromatic & Highly heterochromatic \\
& & Multibanded \\
\hline
\end{tabular}

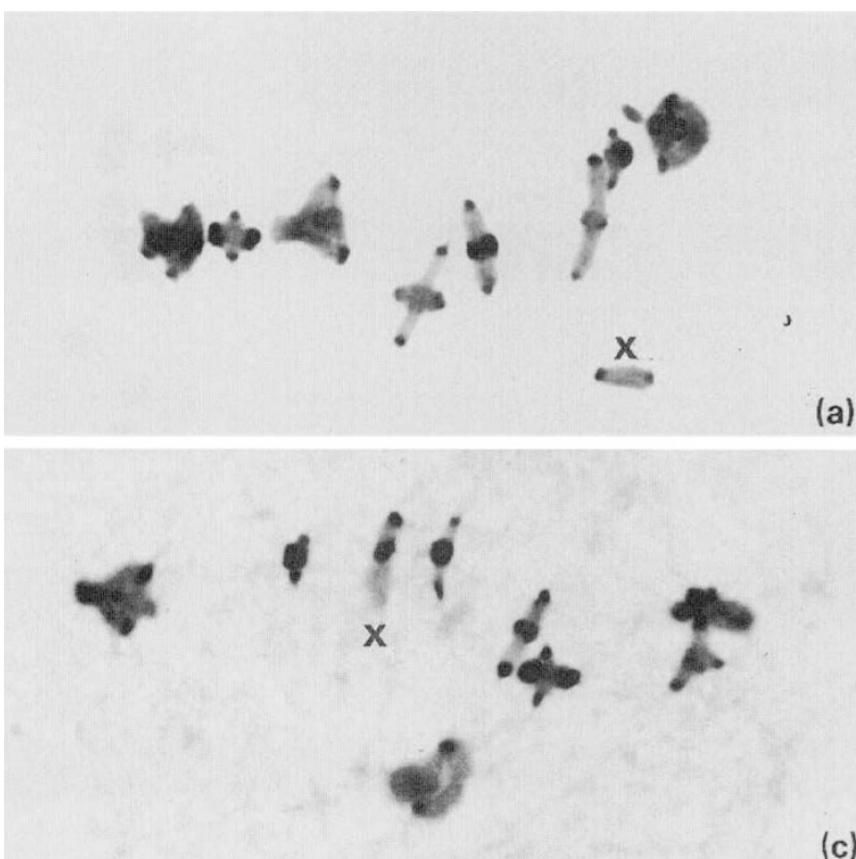

At Col de la Quillane the Cpp X C-band is also found in all individuals south of the morphological-behavioural centre of the hybrid zone, which is near the barrage of Lac Matemale, as far as Llo, a distance of some $15 \mathrm{~km}$ ! South of this into the valley of the Segre all collections have the Cpe X C-band patterns. Our collections were less concentrated this far south of the hybrid zone centre and consequently it is not possible to define a width for the $\mathrm{X} \mathrm{C}$-band cline but only one population was mixed for the two types (Llo), Cpp and Cpe, and no individuals had both bands.

\section{Discussion}

Our collections for Col du Pourtalet happen to define the cline for the X C-band pattern more accurately than for Col de la Quillane. We will therefore discuss

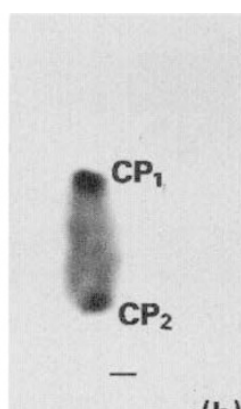

(b)

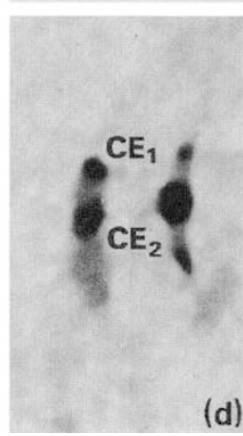

Fig. 2 C-banded metaphase meiocytes from C.p. parallelus (a) and C.p. erythropus (c). Selected X chromosomes show distinct heterochromatin distribution in each subspecies $(b$ and d). Bands CP1 and CE1 correspond to centromeric regions in $C p p$ and $C p e$ whereas $\mathrm{CP} 2$ and $\mathrm{CE} 2$ are characteristic of $C p p$ and $C p e$, respectively.

the results from Col du Pourtalet and refer to Col de la Quillane where it seems relevant.

The first thing to establish is what the $\mathrm{X} \mathrm{C}$-band pattern means in terms of $\mathrm{X}$ chromosome structure in the hybrid zone. The $\mathrm{X}$ chromosomes from the north and south of the transects deep into France and Spain are presumably pure $C p p$ and $C p e$, respectively; we have no evidence to the contrary. Indeed, the sharp cline from $C p p \mathrm{X}$ C-band pattern to that of Cpe argues for a sudden change from pure $C p p$ to $C p e \mathrm{X}$ chromosome, the width of the cline being determined by a difference between dispersal and selection against heterozygotes and/or recombinants (Barton \& Hewitt, $1985,1989)$. Such a narrow cline would indicate strong selection, given that the grasshopper has a dispersal rate (standard deviation of parent-offspring distance) of $30 \mathrm{~m} /$ generation (Virdee \& Hewitt, 1990). 
Table 2 Frequency distribution of the distal parallelus type C-band on the $\mathrm{X}$ chromosome of Chorthippus parallelus males across two Pyrenean cols, Col du Pourtalet and Col de le Quillane. The populations given for each col range across the hybrid zone from pure C.p. parallelus in France to pure C.p. erythropus in Spain

\begin{tabular}{llrlrc}
\hline Population & $\begin{array}{l}\text { Parallelus } \\
\text { X band }(\%)\end{array}$ & $\begin{array}{c}\text { Total } \\
\text { individuals }\end{array}$ & Population & $\begin{array}{c}\text { Parallelus } \\
\text { X band }(\%)\end{array}$ & $\begin{array}{l}\text { Total } \\
\text { individuals }\end{array}$ \\
\hline Pourtalet & & & CP2 & 60 & 20 \\
& & & ORB2 & 100 & 9 \\
Laruns & 100 & 32 & ORB1 & 27 & 11 \\
GA & 100 & 25 & SG-6 & 90 & 21 \\
QB & 100 & 3 & SG-5 & 10 & 30 \\
PLW & 100 & 11 & CCS2 & 43 & 7 \\
PLB & 100 & 11 & CCS & 8 & 12 \\
PLE & 100 & 9 & FO & 0 & 8 \\
TPE & 100 & 5 & SG-4 & 0 & 25 \\
PEB & 100 & 5 & SG & 0 & 25 \\
CP & 100 & 5 & Panticosa & 0 & 21 \\
CAW17 & 100 & 13 & Biescas & 0 & 18 \\
CAS & 100 & 15 & & & \\
CAB & 100 & 9 & & & \\
CAE & 100 & 11 & Quillane & & \\
CP3W18 & 100 & 13 & & & \\
CP3W17 & 100 & 12 & Aunat & 100 & 8 \\
CPE5 & 100 & 5 & FONT & 100 & 6 \\
CPE4 & 100 & 5 & ESC & 100 & 12 \\
CPE3 & 100 & 5 & QM3 & 100 & 6 \\
CPE & 100 & 5 & LM & 100 & 6 \\
CPE1 & 100 & 5 & QM1 & 100 & 7 \\
CPE2 & 100 & 5 & QN & 100 & 9 \\
CP3Ea & 100 & 6 & RJ & 100 & 5 \\
CP3Eb & 100 & 17 & LLAG & 100 & 7 \\
CP3 & 100 & 6 & ML & 100 & 9 \\
IAB & 100 & 10 & STP & 100 & 8 \\
CMup & 100 & 10 & LLO & 86 & 8 \\
CM & 100 & 8 & BOL & 0 & 7 \\
CMa & 85 & 13 & BELL & 0 & 8 \\
\hline & & & & & \\
\hline
\end{tabular}

In an $F_{1}$ hybrid female between the two subspecies we would expect the two different Xs to pair and recombine. The chiasma distribution in this group of grasshoppers (Hewitt, 1979) would usually recombine the interstitial and distal bands of the two subspecies and we have observed such possible recombinant patterns in mixed populations at ORB and LLO. It is also possible that double crossover and proximal crossovers produce segmentally recombined $\mathrm{X}$ chromosomes which possess the parental X C-band pattern; however, the sharpness of the cline indicates that selection rapidly removes recombinants or at least that the $C p p$ and Cpe $\mathrm{X} \mathrm{C}$-bands and the gene combinations in which they are embedded are largely incompatible. Clearly more data are required to resolve these fascinating possibilities.
At Col du Pourtalet the position of the narrow X C-band cline is some $5 \mathrm{~km}$ south of the col itself which is the overall centre of the clines for morphological and behavioural characters. Figure 3 compares the $\mathrm{X}$ $\mathrm{C}$-band cline with clines for two characters which are representative diagnostic features, i.e. stridulatory peg number and ovipositor length. Table 3 gives the cline widths and centres for morphological and behavioural characters (Butlin et al., 1991). It appears that the X $\mathrm{C}$-band cline is the most eccentric of all those we have measured; only female pronotum ratio approaches it so far south of the Col. It is also one of the sharpest clines, most having widths between 8 and $20 \mathrm{~km}$ with only male pronotum ratio being narrower (less than $1 \mathrm{~km}$ ).

In contrast, the X C-band cline at Col de la Quillane is three times as far south of the zone centre $(\sim 15 \mathrm{~km})$ 

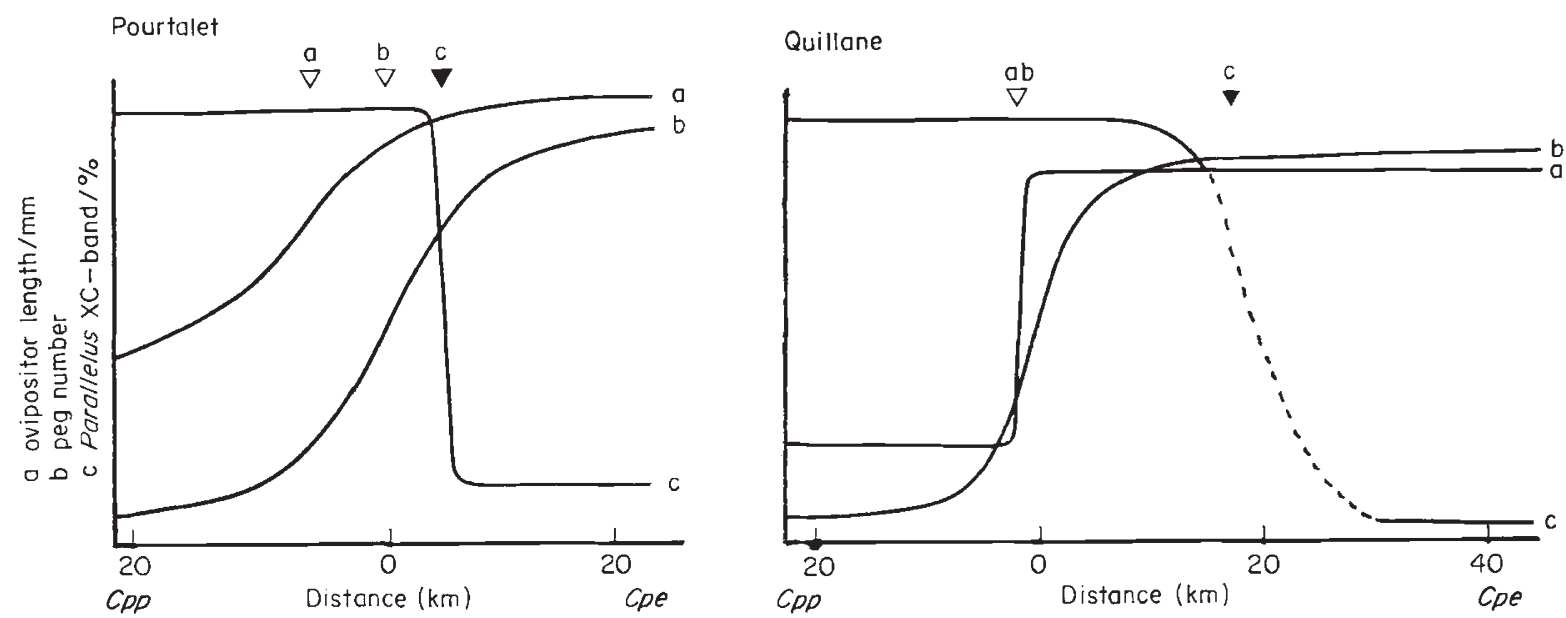

Fig. 3 Cline width and position of the parallelus XNOR C-band compared with clines of other representative characters. The distance 0 represents the centre of the cline for peg number which is coincident with the position of the border in $\mathrm{Col}$ du Pourtalet and the dam of Lac Matemale at Col de la Quillane. At Pourtalet the X C-band cline is very narrow whereas at Quillane there is insufficient data to estimate the cline width. The X C-band cline centre $(\boldsymbol{\Delta})$ is displaced to the south of both cols.

Table 3 Cline width and displacement for one behavioural and six morphological characters in two Pyrenean cols

\begin{tabular}{|c|c|c|c|c|c|c|c|c|}
\hline \multirow[b]{3}{*}{ Character } & \multicolumn{4}{|c|}{ Pourtalet } & \multicolumn{4}{|c|}{ Quillane } \\
\hline & \multicolumn{2}{|l|}{ Males } & \multicolumn{2}{|c|}{ Females } & \multicolumn{2}{|c|}{ Males } & \multicolumn{2}{|c|}{ Females } \\
\hline & $d$ & $w$ & $d$ & $w$ & $d$ & $w$ & $d$ & $w$ \\
\hline Peg number & 0 & 7.9 & - & - & 0 & 8.3 & - & - \\
\hline Hindwing length & $5.6 \mathrm{~N}$ & 20.2 & - & - & $0.4 \mathrm{~N}$ & 2.7 & $1.2 \mathrm{~N}$ & 0.5 \\
\hline Wing ratio & $3.8 \mathrm{~S}$ & 11.3 & - & - & $0.3 \mathrm{~N}$ & 2.7 & - & - \\
\hline Lateral sclerite & - & - & $1.9 \mathrm{~S}$ & 2.9 & - & - & $1.2 \mathrm{~N}$ & 0.2 \\
\hline Pronotum length & $0.4 \mathrm{~N}$ & 0.2 & $0.3 \mathrm{~S}$ & 1.1 & - & - & $1.0 \mathrm{~S}$ & 0.2 \\
\hline Femur ratio & $2.5 \mathrm{~N}$ & 21.2 & $1.4 \mathrm{~N}$ & 36.4 & $2.4 \mathrm{~N}$ & 8.4 & - & - \\
\hline Courtship song & - & 28.0 & - & - & $3.8 \mathrm{~S}$ & 4.2 & - & - \\
\hline
\end{tabular}

Data for both sexes are given where possible.

Displacement $(d)$ is calculated as the distance $(\mathrm{km})$ between the cline centre and the centre of the cline for stridulatory peg number.

Cline widths $(w ; \mathrm{km})$ are calculated after Butlin et al. (1991).

while the other clines are much more coincident and much narrower overall (Table 3, Fig. 3). We have suggested (Butlin et al., 1991) that the differences in degrees of coincidence for morphological characters result from a difference in population structure between the cols: the patchy distribution of grasshoppers at Col du Pourtalet produces wider, more dispersed clines whereas a sharp break in distribution caused by forest and lake tends to concentrate the changes over a shorter distance at Col de la Quillane. Thus it is all the more surprising to find the X C-band changeover so far south of the Col de la Quillane and this suggests that forces other than the ones we have so far considered may be, or have been, at work.

It seems probable that C.p. parallelus and C.p. erythropus met in these high cols following the Younger Dryas at the end of the last ice age when they advanced up the mountains from the north and south sides, respectively (Hewitt, 1989). Evidence from pollen cores near Col de la Quillane indicates a date around $9500 \mathrm{BP}$ (Reille, 1990). This initial contact is likely to have been patchy and intermittent with a few favourable locations becoming habitable at first, and the climate ameliorating with cyclic and erratic fluctuations 
(Hewitt, 1990, 1993). Such dynamics could produce wide clines for those characters showing no differential selection (R. A. Nichols \& G. M. Hewitt, unpublished data) whereas differences producing hybrid unfitness would progress to a narrower clinal equilibrium between dispersal and selection. This type of pioneer mixing may also allow the reassortment of subspecific differences in the ephemeral founder populations, so that as these expand with better climatic conditions to populate the cols, the clines which emerge may not be coincident (Hewitt, 1993). A small number of possible reassortments of components of hybrid zones have been reported, e.g. Vandiemenella viatica (Hewitt, 1979), Mus musculus/domesticus (Gyllensten \& Wilson, 1987; Searle, 1991), Caledia captiva (Marchant et al., 1988), Notropis chrysocephalus/cornutus (Dowling \& Hoeh, 1991) with some of these involving the uncoupling of mtDNA from the main hybrid zone cluster of clines. The advent of more markers provided by DNA techniques along with broad and detailed sampling may well reveal more. The C $P p \mathrm{X}$ C-band introgression into the Cpe genome's territory may have been produced in this manner.

Introgression has occurred to the south in both cols and this may well have been the result of another directional force operating; pioneer population genome reassortment is itself random in direction. Such a tendency could have been provided by the preferential homogamy we have discovered that favours C.p. parallelus progeny in $F_{1}$ crosses (Bella et al., 1992). When mated with both $C p p$ and $C p e$ males, $C p p$ females produce more $C p p$ than hybrid progeny, and this homogamy is stronger than the reverse when Cpe females are likewise mated with both $C p p$ and $C p e$ males. This will tend to push the $C p p$ genome forward. But the genes responsible for its functioning are likely to be disaggregated by recombination in backcrosses and further intercrossing as the hybrid zone develops following secondary contact. It is possible, however, that segements of the chromosomes carrying the genes for homogamy may retain this capacity while becoming segregated from the rest of their own subspecific genomes as the mixing develops. Perhaps the X C-band marks such a region and this has promoted the displacement of the Cpp $\mathrm{X}$ (or part of it) into the Cpe genome. This process may have come to halt now following further recombination into a $C p e$ genome. So far south of the zone centre the genome must be largely C.p. erythropus.

As mentioned previously the narrowness of the $\mathrm{X}$ $\mathrm{C}$-band cline indicates that there is selection of some form against the hybrids, heterozygotes or recombinants. There are a number of possibilities for this selection. First, it is in principle possible that the $\mathrm{X}$ chromosome is carrying genes which are adaptive to different ecological conditions on either side of the $\mathrm{X}$ $\mathrm{C}$-band changeover; that is to say the position of the $\mathrm{X}$ $\mathrm{C}$-band cline is environmentally determined. However, such a sharp change would require a strong selection by a considerable ecological difference. Contrary to our expectation of an environmental change at the Col, recent detailed vegetation analysis indicates an abrupt edaphic change in the region of the $\mathrm{X} \mathrm{C}$-band cline (Virdee, 1991). However, a significant ecological change would be expected to reflect other adaptive differences in the diverged genomes of $C p p$ and $C p e$, so that other characters would change in the same region. As already pointed out, other clines occur north of the $\mathrm{X} \mathrm{C}$-band cline and are centred around the Col du Pourtalet and this disjunction of other clines is even more evident at Col de la Quillane. The resolution of such an environmental explanation will require a combination of detailed vegetational analysis (c.f. Virdee, 1991) and chromosome C-banding throughout this area.

The second possible type of selection that could produce such a sharp X C-band cline concerns its association with a nucleolar organizing region, which is the site of repetitive ribosomal DNA. As C $P p$ has three NORs on the $\mathrm{L}_{2}, \mathrm{~L}_{3}$ and $\mathrm{X}$ chromosomes whereas Cpe has only two on the $\mathrm{L}_{2}$ and $\mathrm{L}_{3}$, it is possible that an imbalance in the number of ribosomal cistrons occurs in hybrid genomes leading to some unfitness in mixed genomes. If this were so, then the fittest genomes should be parental ones, containing either the $\mathrm{L}_{2}, \mathrm{~L}_{3}$ and X NORs and any cryptic sites of rDNA of Cpps or the $\mathrm{L}_{2}$ and $\mathrm{L}_{3}$ NORs and cryptic sites of $C p e$. This would predict that all these rDNA sites, particularly the $L_{2}$ and $L_{3}$ NORs, should change at the same place as the XNOR marked by the X C-band. On present evidence this would perhaps seem unlikely as the $\mathrm{L}_{2}$ and $\mathrm{L}_{3}$ chromosomes will carry genes for characters other than the rDNA, and as we have emphasized other clines do not change over with the $\mathrm{X} \mathrm{C}$-band but at the cols. We have little idea of the epistatic interactions that are involved here and a number of other possibilities exist for selection on the rDNA genes which require an investigation of the number, type, position and activity of ribosomal cistrons in the genomes of the two subspecies and in the hybrid zone. At present it would seem likely that differences in rDNA would cause some selection in the hybrid zone but it is less likely that this plays a major role in the $\mathrm{X} \mathrm{C}$-band cline.

Thirdly, it may be that heterozygote disadvantage is produced by recombination of the Cpp and Cpe $\mathrm{X}$ chromosomes, with the recombinant $\mathrm{X}$ chromosomes causing reduced fitness. Each parental $\mathrm{X}$ chromosome may function normally when all its well adapted alleles 
are together but not if they are mixed with those of the other subspecies. We have observed possible recombinant $\mathrm{X}$ chromosomes with both interstitial and distal $\mathrm{C}$-bands in the mixed populations that mark the cline and will investigate this further,

We may also recall that the $\mathrm{X}$ chromosome has been implicated in species divergence where it seems more prevalent to the accumulation of isolating differences (Coyne \& Orr, 1989). The fact that this introgression has been observed for the $\mathrm{X}$ chromosome may be fortuitous or it may be that it is less likely to have developed in other parts of the genome.

At present we cannot distinguish with any certainty between these hypotheses and need further data to challenge each of them. Perhaps the more likely explanation is that recombinant Xs produce most of the reduction in fitness and asymmetrical homogamy favouring the $C p p \mathrm{X}$ chromosome has pushed it into Cpe territory during secondary contact.

\section{Acknowledgements}

We would like to thank Drs S. R. Virdee and J. L. Bella for help collecting specimens and the SERC, CICYT and EEC (Twinning Project) for financial support.

\section{References}

BARTON, N. H. 1979. The dynamics of hybrid zones. Heredity, 43, 341-359.

BARTON, N. H. AND HEWITT, G. M. 1981. Hybrid zones and speciation. In: W. R. Atchley and D. S. Woodruff (eds.) Evolution and Speciation: Essays in Honour of M. J.D. White, Cambridge University Press, Cambridge, pp. 109-145.

BARTON, N. H. AND HEWITT, G. M. 1985. Analysis of hybrid zones. Ann. Rev. Ecol. Syst., 16, 113-148

BARTON, N. H. AND HEWITT, G. M. 1989. Adaptation, speciation and hybrid zones. Nature, 341, 497-503.

BELLA, J. L., BUTLIN, R. K., FERRIS, C. AND HEwITT, G. M. 1992. Asymmetrical homogamy and unequal sex ratio from reciprocal mating-order crosses between Chorthippus parallelus subspecies. Heredity, 68, 345-352.

BELLA, J. L., GARCIA DE LA VEGA, C., LOPEZ-FERNANDEZ, C. AND GOSALVEZ, J. 1986. Changes in acridine orange binding and its use in the characterisation of heterochromatic regions. Heredity, 57, 79-83.

Bella, J. L., HewitT, G. M. AND Gosalvez, J. 1990. Meiotic imbalance in laboratory-produced hybrid males of Chorthippus parallelus parallelus and Chorthippus parallelus erythropus. Genet. Res. Camb., 56, 43-48.

BUTLIN, R. K. AND HEWITT, G. M. 1985. A hybrid zone between Chorthippus parallelus parallelus and C. p. erythropus (Orthoptera: Acrididae): morphological and electrophoretic characters. Biol. J. Linn. Soc., 26, 269-285.
BUTLIN, R. K. AND RITCHIE, M. G. 1991. Variation in female mate preference across a grasshopper hybrid zone. J. Evol. Biol., 4, 227-240.

BUTLIN, R. K., RITCHIE, M. G. AND HEWITT, G. M. 1991. Comparisons among morphological characters and between localities in the Chorthippus parallelus hybrid zone (Orthoptera: Acrididae). Phil. Trans. R. Soc. Lond. B, 334, 297-308.

COYNE, J. A. AND ORR, H. A. 1989. Two rules of speciation. In: Otte, D. and Endler, J. A. (eds.) Speciation and its Consequences, Sinauer Associates, Sunderland, MA, pp. 180-207.

DOWLING, T. E. AND HOEH, W. R. 1991. The extent of introgression outside the contact zone between Notropis cornutus and Notropis chrysocephalus (Teleostei: Cyprinidae). Evolution, 45, 944-956.

GOSALVEZ, J., LOPEZ-FERNANDEZ, C., BELLA, J. L., BUTLIN, R. K. AND HEwITT, G. M. 1988. A hybrid zone between Chorthippus paralleleus parallelus and Chorthippus parallelus erythropus (Orthoptera: Acrididae): chromosomal differentiation. Genome, 30, 656-663.

GYLLENSTEN, U. AND WILSON, A. C. 1987. Interspecific mitochondrial DNA transfer and the colonisation of Scandinavia by mice. Genet. Res. Camb., 49, 25-29.

HEWITT, G. M. 1975. A sex-chromosome hybrid zone in the grasshopper. Podisma pedestris (Orthoptera: Acrididae). Heredity, 35, 375-385.

HEwITT, G. M. 1979. Animal Cytogenetics. III. Orthoptera. Gebruder Borntraeger, Stuttgart.

HEWITT, G. M. 1985. The structure and maintenance of hybrid zones - with some lessons to be learned from alpine grasshoppers. In: Gosalvez, J., Lopez-Fernandez, C. and Garcia de la Vega, C. (eds) Orthoptera, Fundacion Ramon Areces, Madrid, pp. 15-54.

HEWITT, G. M. 1988. Hybrid zones - natural laboratories for evolutionary studies. Trends Ecol. Evol., 3, 158-167.

HEWITT, G. M. 1989. The subdivision of species by hybrid zones. In: Otte, D. and Endler, J. A. (eds) Speciation and its Consequences, Sinauer Associates, Sunderland, MA, pp. 85-110.

HEWITT, G. M. 1990. Divergence and speciation as viewed from an insect hybrid zone. Can. J. Zool., 68, 1701-1715.

HEWITT, G. M. 1993. After the ice - parallelus meets erythropus in the Pyrenees. In: Harrison, R. G. (ed.) Hybrid Zones and the Evolutionary Process, Oxford University Press, Oxford (in press).

MALLETT, J. AND BARTON, N. H. 1989. Strong natural selection in a warning-color hybrid zone. Evolution, 43, 421-431.

MALLETT, J., BARTON, N. H., LAMAS, M. G., SANTISTEBAN, C. J., MUEDAS, M. M. AND EELEY, H. 1990. Estimates of selection and gene flow from measures of cline width and linkage disequilibrium in Heliconius hybrid zones. Genetics, 124, 921-936.

MARChANT, A. D., ARNOLD, M. L. AND WILKINSON, P. 1988. Gene flow across a chromosomal tension zone. 1. Relics of ancient hybridization. Heredity, 61, 321-328.

MOULIA, C., AUSSEL, J. P., BONHOMME, F., BOURSOT, P., NIELSEN, J. T. AND RENAUD, F. 1992. Wormy mice in a hybrid zone - a genetic-control of susceptibility to parasite infection. $J$. Evol. Biol., 4, 679-687. 
NICHOLS, R. A. AND HEWITT, G. M. 1986. Population structure and the shape of a chromosomal cline between two races of Podisma pedestris (Orthoptera: Acrididae). Biol. J. Linn. Soc., 29, 301-316.

NICHOLS, R. A. AND HEWITT, G. M. 1988. Genetical and ecological differentiation across a hybrid zone. Ecol. Entomol., 13, 39-49.

REILlE, M. 1990. La tourbière de la Borde (Pyrénées orientales, France): un site clé pour l'étude du Tardiglaciare sud-européen. C. R. Acad. Sci., Paris, S. II, 310, 823-829.

SEARLE, J. B. 1991. A hybrid zone comprising staggered chromosomal clines in the house mouse (Mus musculus domesticus). Proc. R. Soc. Lond. B., 246, 47-52.

SHAW, D. D., COATES, D. J., ARNOLD, M. L. AND WILKINSON, P. 1985. Temporal variation in the chromosomal structure of a hybrid zone and its relationship to karyotypic repatterning. Heredity, 55, 293-306.
SZYMURA, J. M. AND BARTON, N. H. 1986. Genetic analysis of a hybrid zone between the fire-bellied toads Bombina bombina and $B$. variegata, near Cracow in Southern Poland. Evolution, 40, 1141-1159.

SZYMURA, J. M. AND BARTON, N. H. 1991. The genetic structure of the hybrid zone between the fire-bellied toads Bombina bombina and $B$. variegata: comparisons between transects and between loci. Evolution, 45, 237-261.

VANLERBERGHE, F., BOURSOT, P., NIELSEN, J. T. AND BONHOMME, F. 1988. A steep cline for mitochondrial DNA in Danish mice. Genet. Res., 52, 185-193.

VIRDEE, S. R. 1991. Ecological and genetic determinants of a hybrid zone in Chorthippus parallelus. Ph.D. thesis, University of East Anglia, Norwich.

VIRDEE, S. R. AND HEWITT, G. M. 1990. Ecological components of a hybrid zone in the grasshopper Chorthippus parallelus (Zetterstedt) (Orthoptera: Acrididae). Bol. San. Veg. Plagas (Fuera de Serie), 20, 299-309. 